\title{
Personality and religion among female university students in France
}

\author{
Christopher Alan Lewis ${ }^{1}$ and Leslie J. Francis ${ }^{2 *}$ \\ ${ }^{1}$ Department of Psychology, Glyndŵw University, UK \\ ${ }^{2}$ Institute of Education, University of Warwick, UK \\ (Received April 8, 2014; Accepted June 18, 2014)
}

\begin{abstract}
The short-form Revised Eysenck Personality Questionnaire was completed by 462 female university students between the ages of 18 and 30 in France, together with the Francis Scale of Attitude toward Christianity. The findings are consistent with those from a series of studies employing the same measure of religiosity among school pupils and adults in England and Wales, thus adding to the cross-cultural evidence concerning the stability of the association between personality and religion. According to these findings there is an inverse relationship between psychoticism and religiosity, while neither neuroticism nor extraversion is either positively or negatively related to religiosity. These findings are discussed in terms of Eysenck's theory relating personality to social attitudes and in light of discrepant findings proposed by other studies conducted among adult samples.
\end{abstract}

Keywords: Eysenck, France, personality, religion.

Personalidad y religión entre los estudiantes del sexo femenino en universidades de Francia

RESUMEN: 462 jóvenes francesas de entre 18 y 30 años cumplimentaron la forma abreviada y revisada del cuestionario de personalidad de Eysenck junto con la escala de actitudes hacia el Cristianismo de Francis. Los resultados son equivalentes a una serie de resultados de estudios utilizando la misma escala de religión entre estudiantes y adultos en Inglaterra y Gales. Según estos resultados, existe una relación inversa entre el psicoticismo y la religión, aunque ni el neuroticismo ni la extraversión tienen una relación positiva o negativa con la religión. Se habla de estos resultados en términos de la teoría de Eysenck que relaciona la personalidad con las actitudes sociales y teniendo en cuenta los resultados discrepantes propuestos por otros estudios con muestras adultas.

Palabras clave: Eysenck, Francia, personalidad, religión.

\section{INTRODUCTION}

During the mid-1970s Argle and Beit-Hallahmi (1975) set out to review the empirical research in the social psychology of religion and assessed the extent to which such research was beginning to establish a secure body of knowledge. At

\footnotetext{
*Correspondence: Warwick Religions \& Education Research Unit, Institute of Education, University 
that time they concluded that the evidence linking personality and religion was both confused and inconclusive. Reassessing that evidence, Francis (1992a) has suggested that the integration of research concerning the connection between personality and religion was made difficult due to three key factors: the range of models of personality or the range of measures of personality employed, the different conceptualisations and different operationalisations of religion employed, and the variety of populations among whom the association has been tested. To address this problem, Francis advocated the power of empirical studies consistently employing the same model of personality and the same aspect of religiosity, but varying the population (see, for example, Francis, Lewis, Brown, Philipchalk, \& Lester, 1995).

In response to Francis' suggestions, a series of recent studies has mapped the personality correlates of the affective dimension of religiosity (employing the Francis Scale of Attitude toward Christianity) among 11-18 year old school pupils within the United Kingdom. All of the studies utilised Eysenck's empirically derived three-dimensional model of personality, which argues that individual differences can be most adequately and economically summarized in terms of the three orthogonal higher order factors: neuroticism-stability, extraversionintroversion, and psychoticism-tendermindedness (Eysenck \& Eysenck, 1985). Four major trends have emerged from these studies.

The first finding is on Eysenck's Neuroticism Scale measure of emotional lability. High scorers on this dimension are characterised as anxious, worrying individuals who are moody and frequently depressed. After controlling for the expected sex differences, according to which females score higher than males on indices of religiosity (Argyle \& Beit-Hallahmi, 1975) and neuroticism (Jorm, 1987), several sets of findings demonstrate no significant relationship between neuroticism scores and religiosity (Francis \& Pearson, 1991; Francis, Pearson, Carter, \& Kay, 1981a; Francis, Pearson, \& Kay, 1983a). This finding contradicts competing theories in the psychology of religion which propose that religion either fosters or reflects neuroticism (Freud, 1950; Vine, 1978), or that it may promote emotional stability (Allport, 1950; Jung, 1938).

In regard to the second finding, Eysenck defines high scorers on the Psychoticism Scale as cold, impersonal, hostile, unemotional, unhelpful, paranoid and tough-minded. In spite of recognized theoretical and empirical difficulties associated with the earlier editions of both the adult (Eysenck, Eysenck, \& Barrett, 1985) and the junior Psychoticism Scales (Corulla, 1990), repeated analyses demonstrate a significant negative relationship between psychoticism scores and religiosity (Francis, 1992b; Francis \& Pearson, 1985a; Kay, 1981). This finding is consistent with Eysenck's central theory relating personality and social attitudes. According to this theory, religion belongs to the domain of tenderminded social attitudes (Eysenck, 1975, 1976). Tenderminded social attitudes are a function of conditioning (Eysenck, 1954, 1961), and individuals who score low on psychoticism have been shown by many empirical studies to condition more readily (Beyts, Frcka, Martin, \& Levey, 1983). 
The third significant finding was on the Extraversion Scale. Eysenck defines the higher scorer on the Extraversion Scale as sociable, outgoing, impulsive, carefree, and optimistic. This definition clearly combines the two notions of sociability and impulsivity (Eysenck \& Eysenck, 1963). While the two components appear to have been more evenly balanced in the earlier editions of the Extraversion Scale, the more recent editions have been largely purified of impulsivity which now relates more closely to psychoticism (Rocklin \& Revelle, 1981). Based on earlier operationalizations of extraversion, introverts emerge as more religious. However, according to the later operationalizations repeated analyses demonstrate no significant relationship between extraversion scores and religiosity (Francis \& Pearson, 1983b; Francis, Pearson, Carter, \& Kay, 1981b; Francis, Pearson, \& Kay, 1985b). This finding is consistent with the evidence of empirical studies which identify impulsivity as the mediating variable within extraversion and psychoticism which is fundamental to conditionability (Pearson, Francis, \& Lightbown, 1986). Thus the removal of the impulsivity component from extraversion vitiates this theoretical basis for associating the personality dimension of extraversion with religiosity.

The final, and fourth consistent finding was on the Lie Scale. Eysenck introduced the Lie Scale into his personality measures in order to detect the faking of questionnaire responses. High scorers on the Lie Scale consistently affirm behaviors which are socially desirable but very unlikely and yet they reject behaviors which are very likely but socially undesirable. Repeated analyses demonstrate a positive significant relationship between Lie Scale scores and religiosity (Francis, Pearson, \& Kay, 1983c, 1988; Pearson \& Francis, 1989).

The theoretical interpretation of this consistent finding is, however, confused by the debate concerning the psychological significance of the Lie Scale (Furnham, 1986). Four main theories on the Lie Scale emerge from this debate. The straightforward view that lie scales measure untruthfulness (O’Donovan, 1969) suggests that religious subjects are bigger liars. The paradoxical view that lie scales actually measure truthfulness (Loo, 1980) proposes the theory that religious subjects are more truthful. The third view suggests that high lie scores indicate lack of self-insight (Crookes \& Buckley, 1976) and leads to the theory that religious subjects are less insightful and less mature. The fourth view suggests that high lie scores indicate social conformity (Massey, 1980) and leads to the view that religious subjects are generally more socially conformist.

Consensus of these focused analyses is given further support by studies conducted among other samples of school pupils in England and Wales, including 8-11 year olds (Robbins, Francis, \& Gibbs, 1995), 9-11 year olds (Francis \& Thomas, 2004), 11 year olds (Francis, Lankshear, \& Pearson, 1989), 12-16 year olds (Francis \& Montgomery, 1992; Williams, Robbins, \& Francis, 2006), 1516 year olds (Francis \& Pearson, 1988), and 16-18 year olds (Francis \& Fearn, 1999; Wilcox \& Francis, 1997). All of these studies among school pupils in England and Wales have measured religion in terms of the Francis Scale of Attitude towards Christianity, using either the junior (Francis, 1978) or adult forms 
of this scale (Francis,1992c; Francis, Lewis, Philipchalk, Brown, \& Lester, 1995, Francis \& Stubbs, 1987).

A second set of studies has extended this research tradition using the Francis Scale of Attitude toward Christianity among school pupils in the Czech Republic (Francis, Quesnell, \& Lewis, 2010), Germany (Francis \& Kwiran, 1999), Hong Kong (Francis, Lewis, \& Ng, 2003), Northern Ireland (Francis, Robbins, ap Siôn, Lewis, \& Barnes, 2007), South Africa (Francis, Kerr, \& Lewis, 2005), and The Netherlands (Francis \& Hermans, 2009).

A third set of studies has employed the Francis Scale of Attitude toward Christianity alongside the Eysenck measures of personality among students and adults, including studies in England and Wales (Bourke \& Francis, 2000; Bourke, Francis, \& Robbins, 2005; Carter, Kay, \& Francis, 1996; Francis, 1991, 1993, 1999; Francis \& Bennett, 1992; Fearn, Lewis, \& Francis, 2003; Williams \& Francis, 2006), Australia and Canada (Francis, Lewis, Brown, Philipchalk, \& Lester, 1995), Germany (Francis, Ziebertz, \& Lewis, 2003), Northern Ireland (Lewis \& Joseph, 1994), Republic of Ireland (Maltby \& Lewis, 1997), the United States of America (Lewis \& Maltby, 1995), and Greece (Youtika, Joseph, \& Diduca, 1999). Once again the basic pattern was confirmed that attitude toward Christianity was negatively correlated with psychoticism, but unrelated to either extraversion or neuroticism, supporting the view that psychoticism is the dimension of personality fundamental to individual differences in religiosity.

However, when varying measures of religiosity are utilised with Eysenck's model of personality there has been varying results. While Wilson and Brazendale (1973), Chlewinski (1981), Caird (1987) and Robinson (1990) confirm the lack of relationship between neuroticism and religiosity, Johnson et al. (1989) report a negative relationship in one of their samples. Meanwhile, Watson, Morris, Foster, and Hood (1986), Heaven (1990), and Biegel and Lester (1990) find evidence for positive relationships. While Wilson and Brazendale (1973) and Chlewinski (1981) confirm the hypothesized negative relationship between religiosity and Eysenck's early measures of extraversion, Siegman (1963), Pearson and Sheffield (1976), and Biegel and Lester (1990) fail to confirm this finding. Similarly, several studies using the more recent editions of Eysenck's personality measures fail to find a consistent negative correlation between religion and psychoticism (Caird, 1987; Heaven, 1990; Robinson, 1990; Watson et al,. 1986). While Wilson and Brazendale (1973), Nias (1973) and Francis and Katz (1992) confirm the positive relationship between religiosity and Lie Scale scores, other studies fail to replicate this consistent pattern (Caird, 1987; Heaven, 1990; Pearson \& Sheffield, 1976; Robinson, 1990; Watson et al., 1986; ).

Francis, Lewis, Brown, Philipchalk, and Lester (1995) argued that the discrepancy between the findings of the studies employing the Francis Scale of Attitude toward Christianity and the wider international literature may be accounted for more readily in terms of the variety of dimensions of religiosity assessed than in terms of different findings being associated with different cultural contexts. As part of an interrelated international set of studies the aim of the present study 
is to advance the debate by exploring the relationship between Eysenck's dimensions of personality and religiosity as measured by the Francis Scale of Attitude toward Christianity among a sample of young adults in France.

\section{METHOD}

\section{Procedure}

As part of their university programme in psychology, undergraduate students were invited to contribute to a study in the field of the psychology of religion by completing a brief questionnaire. Participation in the study was voluntary, with confidentiality and anonymity assured.

\section{Instruments}

The French translation of the abbreviated form Revised Eysenck Personality Questionnaire (Francis, Brown, \& Philipchalk, 1992) proposes four six-item measures of extraversion, neuroticism, psychoticism and the Lie Scale. Each item is assessed on a dichotomous scale: yes and no.

The French translation of the Francis Scale of Attitude toward Christianity (Lewis \& Francis, 2003) is a 24-item Likert type scale concerned with assessing affective response to five aspects of the Christian tradition, namely God, Jesus, Bible, prayer and church. Each item is assessed on a five point scale: agree strongly, agree, not certain, disagree and disagree strongly.

\section{Participants}

The participants comprised 462 female university students between the ages of 18 and 30 in France. Of the total participants, 140 were aged 18 or 19, 233 were aged 20 or 21,70 were aged 22 or 23 and 19 were aged 24 or over. Nearly one in five (18\%) never attended church, while 5\% attended weekly. The remaining $77 \%$ attended church occasionally.

\section{Data Analysis}

The data were analysed by the SPSS statistical package, using the frequency, reliability and correlation routines. 


\section{RESULTS}

Table 1. Reliability Coefficients and Mean Scale Scores by Sex

\begin{tabular}{lcrr}
\hline \multirow{2}{*}{ Scales } & alpha & \multicolumn{3}{c}{ female } \\
& & & mean \\
\hline Extraversion & .73 & 3.8 & 1.7 \\
Neuroticism & .64 & 3.4 & 1.6 \\
Psychoticism & .47 & 1.9 & 1.1 \\
Lie Scale & .53 & 2.7 & 1.6 \\
Attitude toward Christianity & .97 & 64.7 & 21.7 \\
& & & \\
\hline
\end{tabular}

Table one presents the reliability of the four personality scales and the scale of attitude toward Christianity in terms of the alpha coefficients (Cronbach, 1951), together with the mean scale scores. These data demonstrate that Francis Scale of Attitude toward Christianity, the Extraversion Scale and the Neuroticism Scale function in a satisfactory manner among the present sample. The Lie Scale and the Psychoticism Scale are, however, less satisfactory. The lower reliability associated with the psychoticism scale is consistent with the known difficulties in operationalising this dimension of personality (Francis, Brown, \& Philipchalk, 1992).

Table 2. Correlations between Personality and Attitude Toward Christianity

\begin{tabular}{lllll}
\hline & $\mathrm{E}$ & $\mathrm{N}$ & $\mathrm{P}$ & $\mathrm{L}$ \\
\hline Attitude toward Christianity & +.03 & +.05 & $-.27^{* * *}$ & +.01 \\
Lie Scale & -.02 & $-.19^{* * *}$ & $-.11^{*}$ & \\
Psychoticism & & & & \\
& +.02 & +.03 & & \\
Neuroticism & $-.20^{* * *}$ & & & \\
\hline
\end{tabular}

Note: $* p<.05 ; * * p<.01 ; * * * p<.001$ 
Table two presents the Pearson correlation coefficients between extraversion, neuroticism, psychoticism, the Lie Scale and attitude toward Christianity. Given the size of the sample, the probability level has been set at one percent. These data demonstrate that there is a significant negative correlation between attitude toward Christianity and psychoticism scores, while attitude toward Christianity is independent of both extraversion scores and neuroticism scores. There is also no significant correlation between attitude toward Christianity and Lie Scale scores.

\section{DISCUSSION}

Three features of these data are worthy of comment. First, the reliability statistics confirm the satisfactory functioning of the French translation of the Extraversion Scale and the Neuroticism Scale of the abbreviated form of the Revised Eysenck Personality Questionnaire and the French translation of the Francis Scale of Attitude toward Christianity among female university students in France. The lower alpha coefficient associated with the Psychoticism Scale is consistent with the functioning of the present English language instrument and does not, therefore, significantly question the French translation. The lower alpha coefficient of the Lie Scale is more problematic and suggests that the translation of this scale should be investigated further.

Second, the pattern of relationships between attitude toward Christianity and Eysenck's three-dimensional model of personality is consistent with the consensus of findings established elsewhere. According to the Pearson correlation coefficients, neither extraversion nor neuroticism is implicated in individual differences in attitude toward Christianity, while psychoticism is significantly negatively correlated with attitude toward Christianity. The centrality of psychoticism in shaping individual differences in religiosity is consistent with Eysenck's theories that religiosity belongs within the domain of tenderminded social attitudes, that tenderminded social attitudes develop as a function of conditioning and that individuals who score low on psychoticism condition more readily.

Third, the lack of a positive correlation between attitude toward Christianity and Lie Scale scores is inconsistent with the consensus established by earlier studies employing the Francis Scale of Attitude toward Christianity among school age samples in the United Kingdom (Pearson \& Francis, 1989). This finding adds further weight to the case that the translation of this scale should be investigated further.

\section{CONCLUSION}

The present study, conducted among a sample of 462 female university students in France, has contributed to a growing body of international research concerned with the location of individual differences in religiosity within Eysenck's three-dimensional model of personality. The findings add further support from a different cultural context to the general conclusion that, when religiosity is ope- 
rationalised in terms of the Francis Scale of Attitude toward Christianity, neither extraversion nor neuroticism is significantly correlated with religiosity, while there remains a significant negative correlation between psychoticism and religiosity.

Further research is now needed to establish whether these relationships remain consistent during later adulthood within France and whether the same pattern of relationships emerge within other cultures between the Eysenckian constructs of extraversion, neuroticism and psychoticism and the Francis Scale of Attitude toward Christianity. At the same time, it would be helpful to employ a battery of other indices of religiosity along this scale of attitude toward Christianity to explore the extent to which the relationship between personality and religiosity varies according to different operational measures of religion.

\section{REFERENCES}

Allport, G.W. (1950). The individual and his religion. New York, NY: Macmillan.

Argyle, M., \& Beit-Hallahmi, B. (1975). The social psychology of religion. London: Routledge and Kegan Paul.

Beyts, J., Frcka, G., Martin, I., \& Levey, A.B. (1983). The influence of psychoticism and extraversion on classical eyelid conditioning using a paraorbital shock UCS. Personality and Individual Differences, 4, 275-283. doi: 10.1016/0191-8869

Biegel, K., \& Lester, D. (1990). Religiosity and psychological disturbance. Psychological Reports, 67, 874. doi: 10.2466/PR0.67.7.874-874

Bourke, R., \& Francis, L.J. (2000). Personality and religion among music students. Pastoral Psychology, 48, 437-444. doi: 10.1023/A1021384303477

Bourke, R., Francis, L.J., \& Robbins, M. (2005). Personality and attitude toward Christianity among church musicians. North American Journal of Psychology, 7, 85-88.

Caird, D. (1987). Religiosity and personality: Are mystics introverted, neurotic, or psychotic? British Journal of Social Psychology, 26, 345-346. doi: 10.1111/j.2044-8309.1987.tb00798.x

Carter, M., Kay, W.K., \& Francis, L.J. (1996). Personality and attitude toward Christianity among committed adult Christians. Personality and Individual Differences, 20, 265-266. doi: 10.1016/0191-8869(95)00172-7

Chlewinski, Z. (1981). Personality and attitude towards religion in Poland. Personality and Individual Differences, 2, 243-245. doi: 10.1016/0191-8869

Corulla, W.J. (1990). A revised version of the Psychoticism Scale for children. Personality and Individual Differences, 11, 65-76. doi: 10.1016/01918869(90)90169-R

Cronbach, L.J. (1951). Coefficient alpha and the internal structure of tests. Psychometrika, 16, 297-334. doi: 10.1007/BF02310555

Crookes, T.G., \& Buckley, S.J. (1976). Lie score and insight. Irish Journal of 
Psychology, 3, 134-136. doi: 10.1080/03033910.1976.10557626

Eysenck, H.J. (1954). The psychology of politics. London: Routledge and Kegan Paul.

Eysenck, H.J. (1961). Personality and social attitudes. Journal of Social Psychology, 53, 243-248. doi: 10.1080/00224545.1961.9922122

Eysenck, H.J. (1975). The structure of social attitudes. British Journal of Social and Clinical Psychology, 14, 323-331. doi: 10.1111/j.2044-8260.1975. tb00188.x

Eysenck, H.J. (1976). Structure of social attitudes. Psychological Reports, 39, 463-466. doi: 10.2466/pr0.1976.39.2.463

Eysenck, H.J., \& Eysenck, M.W. (1985). Personality and individual differences: A natural science approach. New York, NY: Plenum Press.

Eysenck, S.B.G., \& Eysenck, H.J. (1963). On the dual nature of extraversion. British Journal of Social and Clinical Psychology, 2, 46-55. doi: 10.1111/j.20448260.1963.tb00375.x

Eysenck, S.B.G., Eysenck, H.J., \& Barrett, P. (1985). A revised version of the Psychoticism Scale. Personality and Individual Differences, 6, 21-29. doi: 10.1007/978-1-4613-2413-3

Fearn, M., Lewis, C.A., \& Francis, L.J. (2003). Religion and personality among religious studies students: A replication. Psychological Reports, 93, 819-822. doi: 10.2466/pr0.2003.93.3.819

Francis, L.J. (1978). Attitude and longitude: A study in measurement. Character Potential, 8, 119-130.

Francis, L.J. (1991). Personality and attitude towards religion among adult churchgoers in England. Psychological Reports, 69, 791-794. doi: 10.2466/ pr0.1991.69.3.791

Francis, L. J. (1992). Religion, neuroticism, and psychoticism. In J. F. Schumaker (Ed.), Religion and mental health (pp. 149-160). New York, NY: Oxford University Press.

Francis, L.J. (1992b). Is psychoticism really the dimension of personality fundamental to religiosity? Personality and Individual Differences, 13, 645-652. doi: 10.1016/0191-8869(92)90235-H

Francis, L.J. (1992c). Reliability and validity of the Francis Scale of Attitude toward Christianity (adult). Panorama, 4 (1), 17-19.

Francis, L.J. (1993). Personality and religion among college students in the UK. Personality and Individual Differences, 14, 619-622. doi: 10.1016/01918869(93)90159-Z

Francis, L.J. (1999). Personality and attitude toward Christianity among undergraduates. Journal of Research on Christian Education, 8, 179-195. doi: 10.1080/10656219909484888

Francis, L.J., \& Bennett, G.A. (1992). Personality and religion among female drug misusers, Drug and Alcohol Dependence, 30, 27-31. doi: 10.1016/03768716(92)90032-8

Francis, L.J., Brown, L.B., \& Philipchalk, R. (1992). The development of an 
abbreviated form of the Revised Eysenck Personality Questionnaire (EPQRA): Its use among students in England, Canada, the USA and Australia. Personality and Individual Differences, 13, 443-449. doi: 10.1016/01918869(92)90073-X

Francis, L.J., \& Fearn, M. (1999). Religion and personality: A study among Alevel students. Transpersonal Psychology Review, 3(2) 26-30.

Francis, L.J., \& Hermans, C.A.M. (2009). Psychological health and attitude toward Christianity: A study among pupils attending Catholic schools in the Netherlands. Journal of Religious Education, 57(2), 47-55.

Francis, L.J., \& Katz, Y. (1992). The relationship between personality and religiosity in an Israeli sample. Journal for the Scientific Study of Religion, 31, 153-162. doi: 10.2307/1387005

Francis, L.J., Kerr, S., \& Lewis, C.A. (2005). Assessing attitude toward Christianity among adolescents in South Africa: The Francis Scale. South African Journal of Psychology, 35, 147-155. doi: 10.1177/008124630503500109

Francis, L.J., \& Kwiran, M. (1999). Personality and religion among secondary pupils in Germany. Panorama, 11, 34-44.

Francis, L.J., Lankshear, D.W., \& Pearson, P.R. (1989). The relationship between religiosity and the short form JEPQ (JEPQ-S) indices of E, N, L and P among eleven year olds. Personality and Individual Differences, 10, 763-769. doi: 10.1016/0191-8869(89)90123-2

Francis, L.J., Lewis, J.M., Brown, L.B., Philipchalk, R., \& Lester, D. (1995). Personality and religion among undergraduate students in the United Kingdom, United States, Australia and Canada. Journal of Psychology and Christianity, 14, 250-262.

Francis, L.J., Lewis, C.A., \& Ng, P. (2003). Psychological health and attitude toward Christianity among secondary school pupils in Hong Kong. Journal of Psychology in Chinese Societies, 4, 231-245.

Francis, L.J., Lewis, J.M., Philipchalk, R., Brown, L.B., \& Lester, D. (1995). The internal consistency reliability and construct validity of the Francis Scale of Attitude toward Christianity (adult) among undergraduate students in the UK, USA, Australia and Canada, Personality and Individual Differences, 19, 949-953. doi: 10.1016/S0191-8869(95)00131-X

Francis, L.J., \& Montgomery, A. (1992). Personality and attitudes towards Christianity among eleven to sixteen year old girls in a single sex Catholic school. British Journal of Religious Education, 14, 114-119. doi: 10.1080/0141620920140208

Francis, L.J., \& Pearson, P.R. (1985a). Psychoticism and religiosity among 15 year olds. Personality and Individual Differences, 6, 397-398. doi: 10.1016/0191-8869(85)90066-2

Francis, L.J., \& Pearson, P.R. (1985b). Extraversion and religiosity. Journal of Social Psychology, 125, 269-270. doi: 10.1080/00224545.1985.9922882

Francis, L.J., \& Pearson, P.R. (1988). Religiosity and the short-scale EPQ-R indices of E, N and L, compared with the JEPI, JEPQ and EPQ. Personality 
and Individual Differences, 9, 653-657. doi: 10.1016/0191-8869(88)90162-6

Francis, L.J., \& Pearson, P.R. (1991). Religiosity, gender and the two faces of neuroticism. Irish Journal of Psychology, 12, 60-68. doi: 10.1080/03033910.1991.10557825

Francis, L.J., Pearson, P.R., Carter, M., \& Kay, W.K. (1981a). The relationship between neuroticism and religiosity among English 15- and 16-year olds. Journal of Social Psychology, 114, 99-102. doi: 10.1080/00224545.1981.9922731

Francis, L.J., Pearson, P.R., Carter, M., \& Kay, W.K. (1981b). Are introverts more religious? British Journal of Social Psychology, 20, 101-104. doi: 10.1111/j.2044-8309.1981.tb00481.x

Francis, L.J., Pearson, P.R., \& Kay, W.K. (1983a). Neuroticism and religiosity among English school children. Journal of Social Psychology, 121, 149-150. Doi: 10.1080/00224545.1983.9924478

Francis, L.J., Pearson, P.R., \& Kay, W.K. (1983b). Are introverts still more religious? Personality and Individual Differences, 4, 211-212. doi: 10.1016/01918869(83)90024-7

Francis, L.J., Pearson, P.R., \& Kay, W.K. (1983c). Are religious children bigger liars? Psychological Reports, 52, 551-554. doi: 10.2466/pr0.1983.52.2.551

Francis, L.J., Pearson, P.R., \& Kay, W.K. (1988). Religiosity and lie scores: A question of interpretation. Social Behavior and Personality, 16, 91-95. doi: 10.2224/sbp.1988.16.1.91

Francis, L.J., Quesnell, M., \& Lewis, C.A. (2010). Personality and religion among secondary school pupils in the Czech Republic. Research in Education, 84, 54-64. doi: 10.7227/RIE. 84.4

Francis, L.J., Robbins, M., ap Sion, T., Lewis, C.A., \& Barnes, L.P. (2007). Psychological health and attitude towards Christianity among Protestant and Catholic sixth-form pupils in Northern Ireland. Pastoral Psychology, 56, 157-164. doi: 10.1007/s11089-007-0092-z

Francis, L.J., \& Stubbs, M.T. (1987). Measuring attitudes towards Christianity: From childhood to adulthood. Personality and Individual Differences, 8 , 741-743. doi: 10.1016/0191-8869(87)90075-4

Francis, L.J., \& Thomas, E.M. (2004). Personality and religion among Welsh speaking 9-11 year olds. Welsh Journal of Education, 12 (2), 99-110.

Francis, L.J., Ziebertz, H.-G., \& Lewis, C.A. (2003). The relationship between personality and religion among undergraduate students in Germany. Archive for the Psychology of Religion, 24, 121-127. doi: 10.1163/157361203X00264

Freud, S. (1950). The future of an illusion. New Haven, CT: Yale University Press.

Furnham, A. (1986). Response bias, social desirability and dissimulation. Personality and Individual Differences, 7, 385-400. doi: 10.1016/01918869(86)90014-0

Heaven, P.C.L. (1990). Religious values and personality dimensions. Personality and Individual Differences, 11, 953-956. doi: 10.1016/0191-8869(90)90277-X Johnson, R.C., Danko, G.P., Darvill, T.J., Bochner, S., Bowers, J.K., Huang, 
Y-H., ... Pennington, D. (1989). Cross cultural assessment of altruism and its correlates. Personality and Individual Differences, 10, 855-868. doi: 10.1016/0191-8869(89)90021-4

Jorm, A.F. (1987). Sex differences in neuroticism: A quantitative synthesis of published research. Australian and New Zealand Journal of Psychiatry, 21, 501-506. doi: 10.3109/00048678709158917

Jung, C.G. (1938). Psychology and religion. New Haven, CT: Yale University Press.

Kay, W.K. (1981). Psychoticism and attitude to religion. Personality and Individual Differences, 2, 249-252. doi: 10.1016/0191-8869(81)90032-5

Lewis, C. A., \& Francis, L. J. (2003). Evaluer l'attitude d'étudiantes universitaires françaises à l'égard du Christianisme: l'Echelle de Francis [Assessing attitude toward Christianity among female university students in France: The Francis Scale]. Sciences Pastorals, 22, 179-190.

Lewis, C.A., \& Joseph, S. (1994). Religiosity: Psychoticism and obsessionality in Northern Irish university students. Personality and Individual Differences, 17, 685-687. doi: 10.1016/0191-8869(94)90142-2

Lewis, C.A., \& Maltby, J. (1995). Religiosity and personality among US adults. Personality and Individual Differences, 18, 293-295 doi: 10.1016/01918869(94)00159-P

Loo, R. (1980). Characteristics of the Eysenck Personality Questionnaire Lie Scale and of extreme lie scorers. Psychology: A Quarterly Journal of Human Behavior, 17, 5-10.

Maltby, J., \& Lewis, C.A. (1997). The reliability and validity of a short scale of attitude toward Christianity among USA, English, Republic of Ireland and Northern Ireland adults. Personality and Individual Differences, 22, 649-654. doi: 10.1016/S0191-8869(96)00244-9

Massey, A. (1980). The Eysenck Personality Inventory Lie Scale: Lack of insight or ...? Irish Journal of Psychology, 4, 172-174.

Nias, D.K.B. (1973). Measurement and structure of children's attitudes. In G.D. Wilson (Ed.), The psychology of conservatism (pp. 93-113). London: Academic Press.

O'Donovan, D. (1969). An historical review of the Lie Scale: With particular reference to the Maudsley Personality Inventory. Papers in Psychology, 3, 13-19.

Pearson, P.R., \& Francis, L.J. (1989). The dual nature of the Eysenckian Lie Scales: Are religious adolescents more truthful? Personality and Individual Differences, 10, 1041-1048. doi: 10.1016/0191-8869(89)90255-9

Pearson, P.R., Francis, L.J., \& Lightbown, T.J. (1986). Impulsivity and religiosity. Personality and Individual Differences, 7, 89-94. doi: 10.1016/01918869(86)90112-1

Pearson, P.R., \& Sheffield, B.F. (1976). Is personality related to social attitudes? An attempt at replication. Social Behavior and Personality, 4, 109-111. doi: 10.2224/sbp.1976.4.1.109 
Robbins, M., Francis, L.J., \& Gibbs, D. (1995). Personality and religion: A study among 8-11 year olds. Journal of Beliefs and Values, 16(1), 1-6. doi: $10.1080 / 1361767950160101$

Robinson, T.N. (1990). Eysenck personality measures and religious orientation. Personality and Individual Differences, 11, 915-921. doi: 10.1016/01918869(90)90272-S

Rocklin, T., \& Revelle, W. (1981). The measurement of extraversion: A comparison of the Eysenck Personality Inventory and the Eysenck Personality Questionnaire. British Journal of Social Psychology, 20, 279-284. doi: 10.1111/ j.2044-8309.1981.tb00498.x

Siegman, A.W. (1963). A cross-cultural investigation of the relationship between introversion, social attitudes and anti-social behaviour. British Journal of Social and Clinical Psychology, 2, 196-208. doi: 10.1111/j.2044-8260.1963. tb00392.x

Vine, I. (1978). Facts and values in the psychology of religion. Bulletin of the British Psychological Society, 31, 414-417.

Watson, P.J., Morris, R.J., Foster, J.E., \& Hood, R.W. (1986). Religiosity and social desirability. Journal for the Scientific Study of Religion, 25, 215-232. doi: 10.2307/1385478

Wilcox, C., \& Francis, L.J. (1997). Personality and religion among A level religious studies students. International Journal of Children's Spirituality, 1(2), 48-56. doi: 10.1080/1364436970010207

Williams, E., \& Francis, L.J. (2006). Personality and attitude toward Christianity among churchgoers: A replication. Psychological Reports, 99, 292-294. doi: 10.2466/PR0.99.5.292-294

Williams, E., Robbins, M., \& Francis, L.J. (2006). Personality and religion among adolescents in Wales. The Psychologist in Wales, 19, 21-22.

Wilson, G.D., \& Brazendale, A.H. (1973). Social attitude correlates of Eysenck's personality dimensions. Social Behavior and Personality, 1, 115-118. doi: 10.2224/sbp.1973.1.2.115

Youtika, A., Joseph, S., \& Diduca, D. (1999). Personality and religiosity in a Greek Christian Orthodox sample. Mental Health, Religion \& Culture, 2, 71 74. doi: 10.1080/13674679908406333 
